\title{
Quantification of Carbon Reduction Effects of Domestic Wood Products for Valuation of Public Benefit ${ }^{1}$
}

\author{
Yoon-Seong Chang ${ }^{2} \cdot$ Sejong $\mathrm{Kim}^{2} \cdot$ Kwang-Mo $\mathrm{Kim}^{2} \cdot$ Hwanmyeong $\mathrm{Yeo}^{3,4}$ • \\ Kug-Bo Shim $\mathbb{D}^{2, \dagger}$
}

\begin{abstract}
This study was carried out to quantify degree of contribution of harvested wood product (HWP) on mitigation of climate change by valuation of public benefits, environmentally and economically. The potential carbon dioxide emission reduction of HWP was estimated by accounting carbon storage effect and substitution effect. Based on 2014 statistics of Korea Forest Service, domestic HWPs were sorted by two categories, such as wood products produced domestically from domestic and imported roundwood. The wood products were divided into seven items; sawnwood, plywood, particle board, fiberboard (MDF), paper (including pulp), biomass (wood pellet) and other products. The carbon stock of wood products and substitution effects during manufacturing process was evaluated by items. Based on the relevant carbon emission factor and life cycle analysis, the amount of carbon dioxide emission per unit volume on HWP was quantified. The amounts of carbon stock of HWP produced from domestic and from imported roundwood were 3.8 million tCO $\mathrm{CO}_{2 \mathrm{eq}}$, and 2.6 million $\mathrm{tCO}_{2 \text { eq. }}$, respectively. Also, each reduction of carbon emission by substitution effect of HWP produced from domestic and imported roundwood was 3.1 million $\mathrm{tCO}_{2 \text { eq. }}$ and 2.1 million $\mathrm{tCO}_{2 \text { eq., }}$ respectively. The results of this study, the amount of carbon emission reduction of HWP, can be effectively used as a basic data for promotion of wood utilization to revise and establish new wood utilization promotion policy such as 'forest carbon offset scheme', and 'carbon storage labeling system of HWP'.
\end{abstract}

Keywords: climate change, public benefit, harvested wood products, carbon sequestration, substitution effect

\section{INTRODUCTION}

The worth of forest can be classified into two groups; direct economic value, such as wood, pulp, mushroom and wild edible greens, and public benefits such as watershed conservation, air purification, recreation and landscape, and carbon sequestration. Value of forest products, such as wood products and mushrooms, can be evaluated by price in the market. However, public benefits of forests, which are not traded in the market, are difficult to assess its economic value. The public benefits of forests are public goods. Therefore, many

\footnotetext{
${ }^{1}$ Date Received February 7, 2018, Date Accepted March 20, 2018

2 Department of Forest Products, National Institute of Forest Science, Seoul 02455, Republic of Korea

${ }^{3}$ Department of Forest Sciences, College of Agriculture and Life Sciences, Seoul National University, Seoul 08826, Republic of Korea

${ }^{4}$ Research Institute of Agriculture and Life Sciences, College of Agriculture and Life Sciences, Seoul National University, Seoul 08826, Republic of Korea

† Corresponding author: Kug-Bo Shim(e-mail: kbshim@korea.kr, ORCID: 0000-0003-2459-2453)
} 
studies to evaluate worth of forests into economical value have been conducted.

In Japan, Research Institute of Mathematical Sciences has published public benefits of its forests, and Forestry and Forest Products Research Institute evaluated the public benefits of forests by eight functions, including absorption of carbon dioxide, substitution of fossil fuel, prevention of surface erosion, prevention of surface collapse, flood mitigation, watershed conservation, water purification, and health \& recreation. Recently, many researches focused on carbon storage effect and substitute effect of wood products (Tonosaki, 2009; Tsunetsugu and Tonosaki, 2010; Fuchigami et al., 2016) were conducted. Forest ecosystem values in the USA were categorized into eight groups such as watershed services (water quantity and quality), soil stabilization and erosion control, air quality, climate regulation and carbon sequestration, biodiversity, recreation and tourism, non-timber forest products and cultural values (Krieger, 2001). Empirical estimation of marginal values and total values of social and environmental (i.e. non-market) benefits of forest in UK was estimated. These social and environmental benefits (SEBs) consist of recreation, landscape, biodiversity, carbon sequestration, air pollution absorption, and water purification (Willis et al., 2000; 2003). FAO(2004) classified the value of forests into private, public and global benefits. Public benefits included nutrients circulation, protection of watersheds, soil conservation, improvement of agricultural productivity, protection against fire, and culture, aesthetic, spiritual values. Global benefits are provision of recreation and tourism, carbon absorption and biodiversity by genetic material which is not known at present but it could be used for medical purposes in the future.

The public benefits of forest in Korea which categorized into six groups such as watershed conservation, prevent of soil erosion, landslide prevention, health and recreation, protection of wildlife and oxygen supply were assessed (Kim et al., 1989; 2005; 2007; 2010). Additional functions of forest including wood production, carbon sequestration and recreation were estimated to account value of new forest resources (Park, 1996). There were not so many researches implemented on public benefits of forest in Korea (Choi et al., 2010; Chang et al., 2016). HWP is not only a carbon storage but also low carbon emission material compared with other replaceable materials by wood such as steel and cement, due to its low carbon emission process during manufacturing. The use of wood products as an energy source to substitute fossil fuel is also possible to reduce carbon dioxide emission. During the 17th conference of the parties of UNFCCC, it was agreed to include wood products, which are produced from domestic roundwood into country`s carbon accounting. However, in Korea, the amount of imported wood products is greater than domestic wood products. Therefore, this study was carried out to quantify degree of contribution of HWP to mitigate climate change by valuation of public benefits, environmentally and economically. The potential carbon dioxide emission reduction of HWP was estimated by accounting substitution effect and carbon storage effect in Korea.

\section{MATERIALS and METHODS}

\subsection{Target Object for Valuation of Public Benefits}

To determine value of public benefit of domestic HWP, the following steps were introduced; i) inventory of domestic HWP was classified, ii) production rate of HWP was calculated, iii) carbon dioxide emission reduction of HWP was estimated by accounting substitution effect and carbon storage effect, iv) value of public benefits was calculated by substitution method which handling treatment cost of carbon capture and storage per $1 \mathrm{CO}_{2}$ ton in coal plant (Fig. 1). 


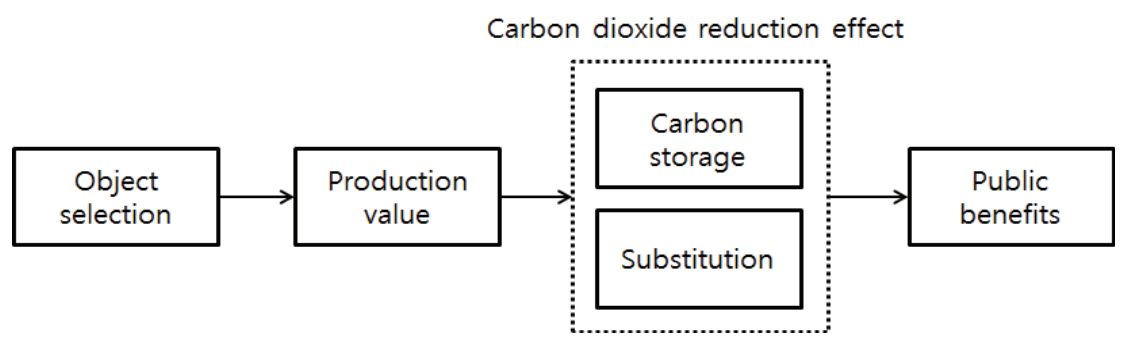

Fig. 1. Flow chart of calculating public benefits of domestic HWP.

To reflect expectation of increasing self-sufficient rate and current status of utilization of domestic HWP, carbon dioxide emission reduction and economic value of wood products produced domestically from domestic roundwood (DRW) and imported roundwood (IRW) were considered. The scope of domestic HWP was classified based on "domestic usage of roundwood" in the "record of wood supply and demand", published by the Korea Forest Service(2015a). They were divided into seven items such as sawnwood, plywood, particle board, fiberboard (MDF), paper(including pulp), biomass(wood pellet) and other products(bed-log and railroad tie). Carbon storage effect and substitution effect of sawnwood, plywood, particle board, and fiberboard were estimated. Carbon storage of paper and other products were estimated and substitution effect of wood pellet was also estimated.

\subsection{Estimation of Carbon Storage Effect and Substitution Effect}

Unit of production rate of HWP was generally cubic meter $\left(\mathrm{m}^{3}\right)$. Domestic production rate of plywood, particle board and fiber board was referred by "statistical yearbook of forestry(Korea Forest Service, 2015b)". The production rate of lumber, paper, other products and wood pellets was calculated by multiplying demand of roundwood in the "record of wood supply and demand" and yield of each products ( 0.5 for pulp, 0.6 for lumber and other products, 0.9 for wood pellet) in "wood utilization actual condition survey(Korea Forest Service, 2015c)" because it is not included in the statistical yearbook of forestry. Production rate of DRW was calculated by multiplying of domestic production rate and percent of domestic HWP. Those factors were derived from four years' average value of "wood utilization actual condition survey (20102013)".

To calculate carbon storage effect of HWP, it was converted to carbon weight by multiplying basic density of HWP and carbon fraction. Carbon dioxide storage capacity of HWP is the same amount of carbon dioxide absorption from atmosphere as its' growing. Carbon dioxide reductions associated with the carbon storage of HWP were estimated by following Equation (1).

$$
\begin{aligned}
& (\text { Carbon storage effect })=(\text { volume }) \times(\text { density }) \\
& \quad \times(\text { carbon fraction }) \times 44 / 12^{*} \cdots \cdots \cdots(1) \\
& * \text { carbon dioxide molecular weight/carbon molecular weight }
\end{aligned}
$$

Greenhouse Gas(GHG) emissions during manufacturing process could be calculated by analyzing the life cycle inventory. If the GHG emission factor of substituted materials and wood products is estimated by unit volume, the emission factor can be greater than actual value. Therefore, to avoid this discrepancy, the GHG emission was estimated based on its weight. Furthermore, the lifespan of the same HWP can be different due to its final usage, for example structural 
member, furniture or interior material. On the other hand, wood pellet can replace fossil fuels, so indirect GHG emissions during fuel production and the direct GHG emissions during combustion of fossil fuel should be considered, simultaneously. Direct carbon dioxide emissions by combustion of biomass was regarded as 'zero' because it was the same amount of absorbed carbon dioxide as its growing. Therefore, the entire direct emission of fossil fuel is included in the substitution effect of wood pellet.

In this study, cement, steel, plastic, gypsum board and kerosene are selected as substituted material of HWP based on its end usage. Substitution effect of HWP was the difference of total GHG emission of substituted materials. The substitution effect was calculated by multiplying GHG emission factor of each substituted materials and distribution ratio of semi-final and final wood products. GHG reduction by substitution effect of HWP was estimated by following equation.

$($ Sub.effect $)=\sum\left(\mathrm{CO}_{2}\right.$ emission by substitution $) \times$ (distribution ratio) - $\left(\mathrm{CO}_{2}\right.$ emission of HWP) $\cdots(2)$

\subsection{Method of public benefit valuation}

In order to calculate public benefit of domestic HWP as carbon storage and substitution material, replacement cost method was applied. Replacement cost method is estimated by the trade cost of environmental material of the substituted goods and services in the market (Shin and Jang, 2006). The cost of afforestation for the production of HWP has not been considered. Therefore, it is the conversion of cost of carbon capture and storage of power plant to carbon reduction credit derived by substitution and storage effect of HWP because main purpose of this study was to estimate the reduction effect associated with the using HWP. Amounts of carbon dioxide emission reduction by carbon storage effect and substitution effect of HWP were converted to average exchange rate of carbon capture and storage cost in 2014 (Euro to USD 1.3289, USD to KRW 1,053.22).

\section{RESULTS and DISCUSSION}

\subsection{Estimation of Carbon Storage Effect and Substitution Effect}

The production amounts of HWP in "report of wood supply and demand" and "statistical yearbook of forestry" were shown in Table 1. Most of domestic roundwood were used for wood panel whereas most of imported roundwood were used for sawnwood.

Carbon stock of HWP in 2014 was calculated by multiplying production amount of HWP and carbon factor (Table 2). Total carbon stock of HWP in 2014 was 6.5 million $\mathrm{tCO}_{2 \text { eq. }}$. Carbon stock of HWP from domestic roundwood and imported roundwood were 3.9 million $\mathrm{tCO}_{2 \text { eq. }}, 2.6$ million $\mathrm{tCO}_{2 \text { eq. }}$, respectively. The

Table 1. Production amount of HWP

\begin{tabular}{|c|c|c|c|c|c|c|c|c|}
\hline & & $\begin{array}{l}\text { sawn } \\
\text { wood }\end{array}$ & $\begin{array}{c}\text { ply } \\
\text { wood }\end{array}$ & $\begin{array}{c}\text { particle } \\
\text { board }\end{array}$ & $\begin{array}{l}\text { fiber } \\
\text { board }\end{array}$ & $\begin{array}{l}\text { paper } \\
\text { (pulp) }\end{array}$ & others & $\begin{array}{l}\text { wood } \\
\text { pellet }\end{array}$ \\
\hline \multirow{3}{*}{$\mathrm{DPH}^{*}$} & Total & 2,397 & 474 & 830 & 2,011 & 455 & 502 & 870 \\
\hline & $\mathrm{DRW}^{* *}$ & 345 & 2 & 759 & 1,689 & 455 & 502 & 870 \\
\hline & $\mathrm{IRW}^{* * *}$ & 2,052 & 472 & 71 & 322 & 0 & 0 & 0 \\
\hline
\end{tabular}

*DPH: domestic production of HWP

** DRW: domestic HWP, produced from domestic roundwood

*** IRW: domestic HWP, produced from imported roundwood 
Yoon-Seong Chang $\cdot$ Sejong Kim $\cdot$ Kwang-Mo Kim $\cdot$ Hwanmyeong Yeo $\cdot$ Kug-Bo Shim

Table 2. Carbon factor to estimate carbon storage effect of HWP (IPCC 2013)

\begin{tabular}{|c|c|c|c|c|c|c|}
\hline & $\begin{array}{l}\text { sawn } \\
\text { wood }\end{array}$ & $\begin{array}{c}\text { ply } \\
\text { wood }\end{array}$ & $\begin{array}{c}\text { particle } \\
\text { board }\end{array}$ & $\begin{array}{l}\text { fiber } \\
\text { board }\end{array}$ & $\begin{array}{l}\text { paper } \\
\text { (pulp) }\end{array}$ & other \\
\hline Density (ton $/ \mathrm{m}^{3}$ ) & 0.458 & 0.542 & 0.596 & 0.691 & 0.900 & 0.500 \\
\hline Carbon fraction & 0.500 & 0.493 & 0.451 & 0.427 & 0.386 & 0.500 \\
\hline
\end{tabular}
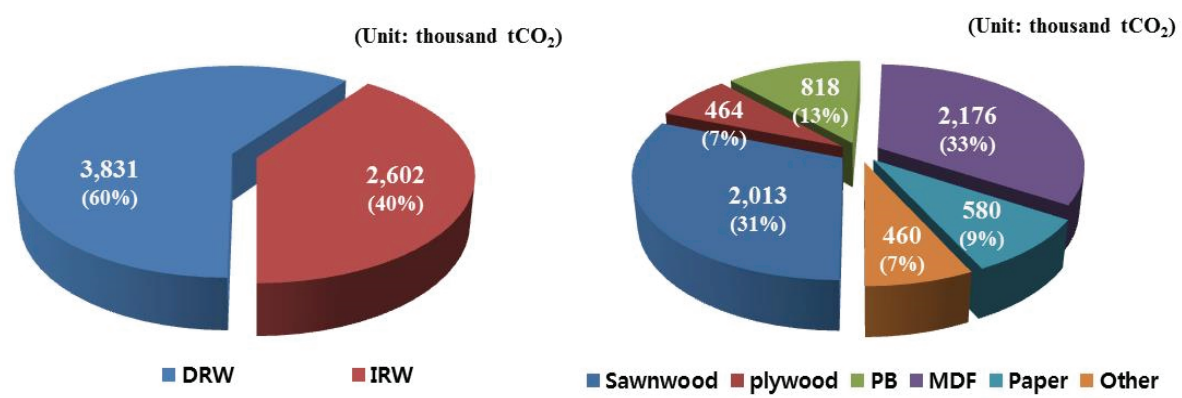

Fig. 2. Carbon storage effect of HWP (by roundwood(left), by products (right)).

carbon stock of fiberboard, sawnwood, and particle board was 2.2 million $\mathrm{tCO}_{2 \text { eq. }}, 2$ million $\mathrm{tCO}_{2 \text { eq. }}, 0.8$ million $\mathrm{tCO}_{\text {2eq. }}$, respectively (Fig. 2).

Since panel products such as MDF or PB are manufactured by wood chips, it is difficult to reuse them to the other products, so their lifespan is shorter than sawnwood. It is possible to produce structural lumber from domestic roundwood to substitute imported one to increase carbon stocks in Korea.

GHG emission factor of HWP (Table 3) and substituted materials (Table 4) such as cement, steel and the distribution ratio by the end use of HWP was considered to assess substitution effect of HWP (Table
5). Difference of transport load between domestic and import HWP was not considered because LCI DB of HWP included average transport load of raw material, such as $\log$.

Since plastic pallet made of polypropylene and kerosene is used for fuel in Korea to produce heat, it was considered main raw material for producing each final substituted materials. Net carbon emission, which is differences of carbon dioxide emissions between HWP and its substituted materials, was $1.42 \mathrm{tCO}_{2 \mathrm{eq}} /$ ton for sawnwood, $1.65 \mathrm{tCO}_{2 \mathrm{eq}} / \mathrm{ton}$ for plywood, 2.67 $\mathrm{tCO}_{2 \mathrm{eq}} /$ ton for particleboard, $1.08 \mathrm{tCO}_{2 \mathrm{eq}} / \mathrm{ton}$ for fiberboard and $1.62 \mathrm{tCO}_{2 \mathrm{eq}} / \mathrm{ton}$ for wood pellet,

Table 3. GHG emission factor of HWP

\begin{tabular}{|c|c|c|c|c|c|}
\hline & sawnwood* & plywood $^{* *}$ & $\mathrm{~PB}^{* * *}$ & $\mathrm{MDF}^{* * *}$ & wood pellet ${ }^{* * *}$ \\
\hline $\begin{array}{l}\text { GHG emission factor, } \\
\text { per volume }\left(\mathrm{tCO}_{2 \mathrm{eq}} / \mathrm{m}^{3}\right)\end{array}$ & 0.178 & $\begin{array}{c}0.348 \\
\text { (ex/interior avr.) }\end{array}$ & 0.332 & 0.472 & 0.065 \\
\hline density (ton $\left./ \mathrm{m}^{3}\right)$ & 0.458 & 0.542 & 0.596 & 0.691 & $\begin{array}{c}0.64 \\
\text { (bulk density) }\end{array}$ \\
\hline $\begin{array}{l}\text { GHG emission factor, } \\
\text { per weight }\left(\mathrm{tCO}_{2 \mathrm{eq}} / \text { ton }\right)\end{array}$ & 0.389 & 0.661 & 0.557 & 0.683 & 0.13 \\
\hline
\end{tabular}

${ }^{*}$ Son et al.(2016), ${ }^{* *}$ Korea Forestry Promotion Institute(2015), ${ }^{* * *}$ Korea Forestry Promotion Institute(2014). 
Quantification of Carbon Reduction Effects of Domestic Wood Products for Valuation of Public Benefit

Table 4. GHG emission coefficient of substituted materials (KEITI 2016)

\begin{tabular}{cccccc}
\hline & portland cement & steel & gypsum board & plastic & kerosene \\
\hline \hline $\begin{array}{c}\text { GHG emission factor, } \\
\text { per volume }\left(\mathrm{tCO}_{\text {2eq. }} / \mathrm{m}^{3}\right)\end{array}$ & 1.793 & 25.194 & 0.172 & 1.323 & 0.211 \\
\hline density $\left(\right.$ ton $\left./ \mathrm{m}^{3}\right)$ & 1.9 & 7.8 & 0.8 & 0.9 & 0.834 \\
\hline $\begin{array}{c}\text { carbon emission factor, } \\
\text { per weight }(\mathrm{tCO} \text { 2eq. } / \text { ton) }\end{array}$ & 0.944 & 3.23 & 0.215 & 1.47 & 0.253 \\
\hline
\end{tabular}

Table 5. Selection of substituted materials and distribution rate of HWP by end use

\begin{tabular}{|c|c|c|c|c|c|c|}
\hline & sawnwood ${ }^{*}$ & plywood* & particle board ${ }^{*}$ & fiber board ${ }^{*}$ & wood pellet ${ }^{* *}$ & $\begin{array}{l}\text { substituted } \\
\text { materials }\end{array}$ \\
\hline structure & $\begin{array}{c}458,774 \\
(19 \%)\end{array}$ & - & - & - & - & cement \\
\hline scaffold & $\begin{array}{c}722,494 \\
(30 \%)\end{array}$ & $\begin{array}{c}293,481 \\
(63 \%)\end{array}$ & - & - & - & steel \\
\hline pallet & $\begin{array}{c}289,469 \\
(12 \%)\end{array}$ & - & - & - & - & plastic \\
\hline package & $\begin{array}{c}311,312 \\
(13 \%) \\
\end{array}$ & $\begin{array}{l}3,605 \\
(1 \%) \\
\end{array}$ & - & $\begin{array}{c}155,999 \\
(7 \%)\end{array}$ & - & plastic \\
\hline furniture & $\begin{array}{c}23,045 \\
(1 \%)\end{array}$ & - & $\begin{array}{c}837,548 \\
(100 \%)\end{array}$ & $\begin{array}{c}967,755 \\
(47 \%)\end{array}$ & - & steel \\
\hline $\begin{array}{c}\text { musical } \\
\text { instrument }\end{array}$ & $\begin{array}{l}9,657 \\
(0 \%)\end{array}$ & - & - & - & - & steel \\
\hline wire drum & $\begin{array}{c}56,994 \\
(2 \%) \\
\end{array}$ & - & - & - & - & plastic \\
\hline deck/flooring & $\begin{array}{c}69,817 \\
(3 \%)\end{array}$ & $\begin{array}{l}54,897 \\
(12 \%)\end{array}$ & - & $\begin{array}{c}78,989 \\
(4 \%)\end{array}$ & - & plastic \\
\hline interior & $\begin{array}{c}307,974 \\
(13 \%) \\
\end{array}$ & $\begin{array}{c}104,956 \\
(22 \%) \\
\end{array}$ & - & $\begin{array}{c}877,290 \\
(42 \%) \\
\end{array}$ & - & gypsum board \\
\hline steel manufacture & $\begin{array}{c}21,121 \\
(1 \%) \\
\end{array}$ & - & - & - & - & steel \\
\hline cartridge box & $\begin{array}{c}380 \\
(0 \%) \\
\end{array}$ & - & - & - & - & steel \\
\hline floating fish cage & $\begin{array}{l}1,664 \\
(0 \%)\end{array}$ & - & - & - & - & plastic \\
\hline farming tool & $\begin{array}{c}644 \\
(0 \%)\end{array}$ & - & - & - & - & steel \\
\hline facilities & $\begin{array}{c}44,535 \\
(2 \%) \\
\end{array}$ & - & - & - & - & steel \\
\hline others & $\begin{array}{c}88,102 \\
(4 \%) \\
\end{array}$ & $\begin{array}{c}11,806 \\
(3 \%)\end{array}$ & - & - & - & plastic \\
\hline fuel & - & - & - & - & $100 \%$ & kerosene \\
\hline total & $2,405,981$ & 468,745 & 837,548 & $2,080,033$ & - & \\
\hline
\end{tabular}

${ }^{*}$ Wood utilization status survey, ${ }^{* *}$ Assumed. 

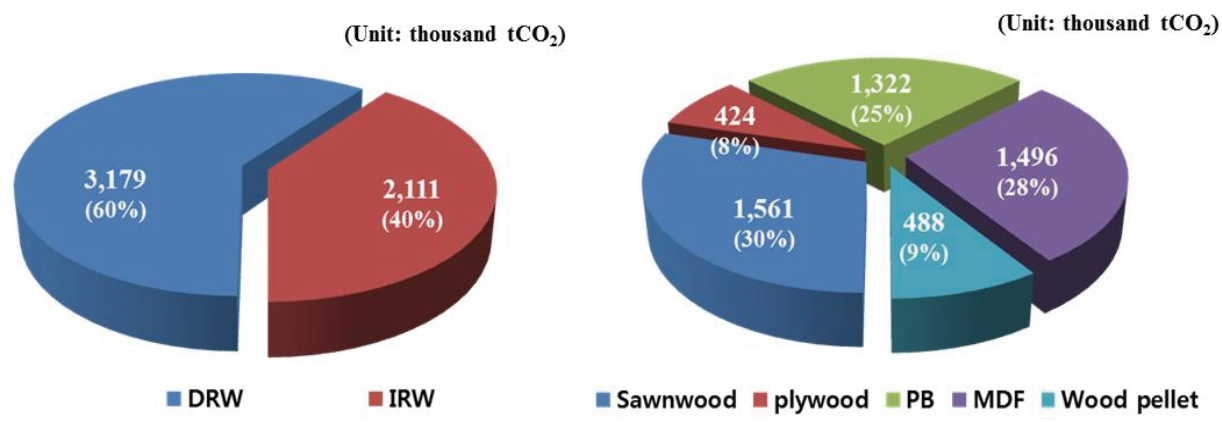

Fig. 3. Substitution effect of HWP (by roundwood(left), by products (right))

respectively. The lower heating value of wood pellets (Nifos 2016) is $4,040 \mathrm{kcal} / \mathrm{kg}$ and that of kerosene is $9,753 \mathrm{kcal} / \mathrm{kg}$ (KEITI 2016). So, $1 \mathrm{~kg}$ kerosene is equivalent to $2.42 \mathrm{~kg}$ wood pellets. Combustion of 1 ton kerosene emitted $2.92 \mathrm{tCO}_{2 \mathrm{eq}}$, therefore Direct GHG reduction effect of 1 ton of wood pellet was assumed as $1.21 \mathrm{tCO}_{2 \mathrm{eq}}$. The substitution effect of particle board was the largest among those HWP. All particle boards produced in Korea were used for furniture manufacturing therefore the particle boards substituted steel which has relatively high GHG emission factor (3.23 $\left.\mathrm{tCO}_{2 \mathrm{eq}} / \mathrm{ton}\right)$. Half of fiberboards were used for building interior material to substitute gypsum board which has relatively low GHG emission factor $(0.215$ $\mathrm{tCO}_{\text {2eq. }}$ /ton). The substitution effect of HWP was assessed by multiplying each HWP's production volume and its GHG emission factor. Total substitution effect of HWP was about 5.3 million $\mathrm{tCO}_{2 \text { eq. }}$ In case of roundwood, substitution effect of HWP from domestic roundwood and imported roundwood were 3.2 million $\mathrm{tCO}_{2 \text { eq. }}$ and 2.1 million $\mathrm{tCO}_{2 \text { eq. }}$, respectively. Sawnwood has the largest share as 1.6 million $\mathrm{tCO}_{\text {2eq. Fiberboard }}$ and particleboard have 1.5 million $\mathrm{tCO}_{2 \text { eq. }}, 1.3$ million $\mathrm{tCO}_{\text {2eq. }}$, respectively (Fig. 3). In case of wood pellets, substitution effect by indirect emissions during fuel production is about 0.1 million $\mathrm{tCO}_{\text {2eq. }}$, the substitution effect by direct emissions during combustion is 0.4 million $\mathrm{tCO}_{\text {2eq. }}$. Wood pellet has large effect following particle board and plywood in terms of substitution effect of HWP per unit weight (1 ton). To maximize utilization efficiency of forest resources to combat climate change, replacement of fossil fuels by biomass from forest residue and by-product of producing HWP should be considered.

\subsection{Valuation of public benefit of domestic HWP}

The amount of carbon dioxide reduction by HWP from domestic roundwood in 2014 was 7 million $\mathrm{tCO}_{2 \mathrm{eq}}$, that from imported roundwood was 4.7 million $\mathrm{tCO}_{2 \mathrm{eq}}$. (Table 6). As the assumption of 90,976 won of carbon capture and storage cost per 1 ton of carbon dioxide, public benefit by domestic and imported HWP was estimated as 644.7 and 428.9 billion won, respectively, and it was 1,073.6 billion won in total.

Currently, HWP used in Korea, for example roundwood and wood products, were mainly imported. However, it is expected to replace imported HWP by domestic HWP, gradually. Because stand age classes of domestic forest has reached its maturity, selfsufficient rate of domestic roundwood has been increasing continuously. It is encouraged to use HWP for long life span wood products such as structural lumber, glued laminated timber.

Based on this study, the development of carbon 
Table 6. Carbon reduction effect of HWP

\begin{tabular}{|c|c|c|c|c|c|c|c|c|c|c|c|}
\hline & & & sawnwood & $\begin{array}{c}\text { ply } \\
\text { wood }\end{array}$ & PB & MDF & $\begin{array}{l}\text { paper } \\
\text { (pulp) }\end{array}$ & $\begin{array}{l}\text { wood } \\
\text { pellet }\end{array}$ & others & Total & $\begin{array}{c}\text { public } \\
\text { benefit value } \\
\text { (billion won) }\end{array}$ \\
\hline \multirow{6}{*}{$\begin{array}{l}\text { D } \\
\text { P } \\
H\end{array}$} & \multirow{3}{*}{$\begin{array}{l}\mathrm{D} \\
\mathrm{R} \\
\mathrm{W}\end{array}$} & Str. & 290 & 2 & 748 & 1,827 & 580 & - & 460 & 3,907 & \\
\hline & & Sub. & 225 & 2 & 1,209 & 1,256 & - & 488 & - & 3,180 & \\
\hline & & Total & 515 & 4 & 1,957 & 3,083 & 580 & 488 & 460 & 7,087 & 645 \\
\hline & \multirow{3}{*}{$\begin{array}{l}\mathrm{I} \\
\mathrm{R} \\
\mathrm{W}\end{array}$} & Str. & 1,723 & 462 & 70 & 348 & - & - & - & 2,603 & \\
\hline & & Sub. & 1,336 & 422 & 113 & 240 & - & - & - & 2,111 & \\
\hline & & Total & 3,059 & 884 & 183 & 588 & 0 & 0 & 0 & 4,714 & 429 \\
\hline \multirow{3}{*}{\multicolumn{2}{|c|}{ Total }} & Str. & 2,013 & 464 & 818 & 2,175 & 580 & 0 & 460 & 6,510 & \\
\hline & & Sub. & 1,561 & 424 & 1,322 & 1,496 & 0 & 488 & 0 & 5,291 & \\
\hline & & Total & 3,574 & 888 & 2,140 & 3,671 & 580 & 488 & 460 & 11,801 & \\
\hline
\end{tabular}

DPH: domestic production HWP

DRW: domestic production HWP from domestic roundwood IRW: domestic production HWP from imported roundwood Str: carbon storage

Sub: Substitution

account model of HWP, including carbon storage effect, and substitution effect, is possible by classification of more accurate domestic substituted material that reflects real situation of wood industry and end-use of each HWP.

\section{CONCLUSION}

The public benefit of wood utilization by quantifying carbon storage effect and substitution effect of HWP in Korea in 2014 was assessed. The amount of carbon dioxide reduction by HWP from domestic roundwood in 2014 was 7 million $\mathrm{tCO}_{2 \text { eq. }}$, that from imported roundwood was 4.7 million $\mathrm{tCO}_{2 \text { eq. }}$. The results of this study can be effectively used as a basic data for promotion of wood utilization to revise and establish new wood utilization promotion policy such as and 'forest carbon offset scheme', and 'carbon storage labeling system of HWP'.

\section{ACKNOWLEDGMENT}

This study was supported by the Research Fellowship Program of the National Institute of Forest Science in 2017.

\section{REFERENCES}

Chang, Y.S., Kim, S.J., Son, W.L., Lee, S.J., Shim, K.B., Yeo, H., Kim, K.M. 2016. Assessment of Carbon Emission for Quantification of Environmental Load on Structural Glued Laminated Timber in Korea. Journal of the Korean Wood Science and Technology 44(3): 449-456.

Chang, Y.S., Kim, S.J., Son, W.L., Lee, S.J., Shim, K.B., Yeo, H., Kim, K.M. 2016. Assessment of Carbon Emission for Quantification of Environmental Load on Structural Glued Laminated Timber in Korea. Journal of the Korean Wood Science and 
Technology 44(3): 449-456.

FAO. 2004. Valuation methods for environmental benefits in forestry and watershed investment projects. p.52.

Fuchigami, Y., Hara, K., Kita, T., Uwasu, M., Kurimoto, S. 2016. Analysis of effect on $\mathrm{CO}_{2}$ emission reduction and cost estimation for the use of Bio-coke: a case study of Osaka, Japan. Journal of Wood Science 62: 93-100.

Intergovernmental Panel on Climate Change. 2013. 2013 Revised Supplementary Methods and Good Practice Guidance Arising from the Kyoto Protocol. Kim, J.H. 1989. Valuation of Nonmarket Forest Resources. Nifos Research Information 29: 1-2. Kim, J.H., Lee, K.H., Park, C.W., Kim, K.H., Youn, H.J., Son, Y.M., Lee, S.W., Park, C.R., Seo, J.W., Oh, J.S. 2005. Valuation of Nonmarket Forest Resources. Nifos Research Report No.05-07. p.244.

Kim, J.H., Kim, J.J., Jeon, J.H., Son, Y.M., Kim, K.H., Youn, H.J., Park, C.R., Lee, S.W. 2007. Valuation of Nonmarket Forest Resources. Nifos Research Report No.07-07. p.354.

Kim, J,H., Kim, K.D., Kim, R.H., Park, C.R., Youn, H.J., Lee, S.W., Choi, H.T., Kim, J.J. 2010. Valuation of Nonmarket Forest Resources. Nifos Research Report No.10-26. p.205.

Korea Forest Service. 2015. Wood supply record.

Korea Forest Service. 2015. Statistical yearbook of forestry.

Korea Forest Service. 2015. Wood utilization actual condition survey.

Korea Environmental Industry \& Technology Institute. 2016. Guideline of Carbon Footprint Labelling Certification.

Korea Forestry Promotion Institute. 2014. Project of Estimation for environmentally friendliness by life cycle inventory database of wood products( I )

Korea Forestry Promotion Institute. 2015. Project of Estimation for environmentally friendliness by life cycle inventory database of wood products( II)
Krieger, D.J. 2001. Economic value of forest system services: A review. p.31.

National Institute of Forest Science. 2016. Notification on Specifications and Quality Standards of Wood Pellets.

Park, D.K. 1996. Development of forest resource account and its use for policy impact analysis: with a special reference to timber, carbon sequestraton, and forest recreation. Doctoral thesis. Seoul National University. Republic of Korea.

Shin, Y.K., Jang, C.S. 2006. A Study of Compensation Structure on Forestry Sector as a Public Good.

Son, W.L., Bang, Y.Y., Kim, S.J. 2016. Evaluation of life cycle inventory of domestic wood products and its environmental impact. Proceeding of 2016 annual meeting of the Korean society of Wood Science and Technology. Seoul, Korea, 15 - 16 April 2016.

Tonosaki, M. 2009. Harvested wood products accounting in the post Kyoto commitment period. Journal of Wood Science 55: 390-394.

Tsunetsugu, Y., Tonosaki, M. 2010. Quantitative estimation of carbon removal effects due to wood utilization up to 2050 in Japan: effects from carbon storage and substitution of fossil fuels by harvested wood products. Journal of Wood Science 56: 339-344.

Willis, K.G., Garrod, G., Scarpa, R., Macmillan, D., Bateman, I. 2000. Non-market benefits of forestry (Phase 1), Report to the Forestry Commission, Centre for Research in Environmental Appraisal and Management, University of Newcastle, Newcastle, United Kingdom. p.126.

Willis, K.G., Garrod, G., Scarpa, R., Powe, N., Lovett, A., Bateman, I.J., Hanley, N., Macmillan, D.C. 2003. The social and environmental benefits of forests in Great Britain (Phase 2), Report to the Forestry Commission, Centre for Research in Environmental Appraisal and Management, University of Newcastle, United Kingdom. 